\title{
PENAMBAHAN KALSIUM PADA AIR RAWA SEBAGAI PENGENCER SALINITAS MEDIA PEMELIHARAAN PASCALARVA UDANG GALAH TERHADAP SINTASAN, TINGKAT KERJA OSMOTIK, DAN KONSUMSI OKSIGEN
}

\author{
Ferdinand Hukama Taqwa"\#), Ade Dwi Sasanti"\#), Khadiful Haramain", \\ Eni Kusrini**), dan Abdul Karim Gaffar ${ }^{* * \# \#)}$ \\ *) Program Studi Akuakultur, Fakultas Pertanian, Universitas Sriwijaya \\ JI. Raya Palembang, Prabumulih KM. 32, Indralaya, Ogan Ilir 30662, Sumatera Selatan \\ E-mail: ferdinand_unsri@yahoo.co.id \\ *) Balai Penelitian dan Pengembangan Budidaya Ikan Hias \\ Jl. Perikanan No. 13, Pancoran Mas, Depok 16436 \\ **) Balai Penelitian Perikanan Perairan Umum (BP3U), Sumsel-KKP RI \\ Jl. Beringin 308 Mariana PO BOX, Palembang 30763 \\ \#) Pusat Unggulan Riset Pengembangan Lahan Suboptimal (PUR-PLSO), \\ Universitas Sriwijaya \\ Jl. Raya Palembang, Prabumulih Km. 32, Inderalaya 30662
}

(Naskah diterima: 19 Maret 2014; Disetujui publikasi: 25 Juli 2014)

\begin{abstract}
ABSTRAK
Budidaya udang galah di lahan suboptimal rawa masih mengalami kendala karena tingkat mortalitas yang tinggi pada stadia pascalarva terutama saat penebaran awal di media air rawa. Kondisi perairan rawa yang kurang sesuai untuk budidaya udang galah perlu ditingkatkan daya dukungnya terutama yang berhubungan dengan kemampuan osmoregulasi dan metabolisme pascalarva udang galah, salah satunya berupa penambahan mineral kalsium. Penelitian ini bertujuan untuk menentukan penambahan kadar kalsium terbaik yang dapat menghasilkan sintasan, tingkat kerja osmotik, dan tingkat konsumsi oksigen terbaik pada pascalarva udang galah selama masa adaptasi pergantian media hidup dari media bersalinitas 12 ppt ke media air rawa 0 ppt, selama 10 hari mulai dari udang galah stadia $\mathrm{PL}_{1}$ hingga $\mathrm{PL}_{11}$ dengan penurunan salinitas secara gradual dan persentase volume. Rancangan percobaan yang digunakan yaitu rancangan acak lengkap dengan lima perlakuan penambahan kalsium pada air rawa pengencer salinitas media, yaitu $0 \mathrm{mg} \cdot \mathrm{L}^{-1}(\mathrm{~A}), 25 \mathrm{mg} \cdot \mathrm{L}^{-1}(\mathrm{~B}), 50 \mathrm{mg} \cdot \mathrm{L}^{-1}(\mathrm{C}), 75 \mathrm{mg} \cdot \mathrm{L}^{-1}$ (D), dan $100 \mathrm{mg}^{-\mathrm{L}^{-1}}$ (E). Parameter yang diamati yaitu tingkat sintasan, tingkat kerja osmotik, tingkat konsumsi oksigen, kadar kalsium tubuh, dan kualitas fisika kimia media adaptasi. Hasil penelitian menunjukkan bahwa penambahan $50 \mathrm{mg} \cdot \mathrm{L}^{-1} \mathrm{kalsium}$ (C) dapat meminimalisir tingkat kerja osmotik terendah yaitu $192,90 \mathrm{mOsm} . \mathrm{I}^{-1} \mathrm{H}_{2} \mathrm{O}$ dan tingkat konsumsi oksigen $2,678 \mathrm{mgO}_{2} \cdot \mathrm{g}^{-1} \cdot \mathrm{jam}^{-1}$. Selain itu, juga dapat menyebabkan kadar kalsium tubuh hingga mencapai $8,029 \mathrm{mg} / \mathrm{L}$ dan sintasan yang diperoleh mencapai 94\%. Selama penelitian berlangsung parameter fisika kimia media adaptasi (suhu, pH, oksigen terlarut, amonia, dan alkalinitas) masih dalam kondisi yang dapat ditolerir bagi sintasan udang galah.
\end{abstract}

KATA KUNCl: kalsium, rawa, salinitas, adaptasi, udang galah, pascalarva 
ABSTRACT: The addition of calcium on swamp water during salinity reduction on survival rate, osmotic work and oxygen consumption level of giant fresh water prawn postlarvae. By: Ferdinand Hukama Taqwa, Ade Dwi Sasanti, Khadiful Haramain, Eni Kusrini, and Abdul Karim Gaffar

\begin{abstract}
Prawn culture in suboptimal swamp lands is still problems because of the high mortality rate in the postlarvae stadium especially when the initial stocking in swamp water media. Swamp water conditions that are less suitable for prawn cultivation, are required to increase its carrying capacity which is mainly related to the ability of osmoregulation and and metabolism prawns postlarvae, one of the way by addition mineral calcium. The research aim was to evaluate the best calcium addition on swamp water for survival, osmotic work level, and oxygen consumption to postlarvae of giant fresh water prawn during the adaptation period from salinity media 12 ppt to 0 ppt swamp water, for 10 days starting from the stadium $P L_{1}$ to $P L_{11}$ prawns by decreasing gradually salinity and substitution the percentage of water volume. The research consisted with 5 treatments and three replication of calcium addition: 0 $\mathrm{mg} \cdot \mathrm{L}^{-1}(A), 25 \mathrm{mg} \cdot \mathrm{L}^{-1}(B), 50 \mathrm{mg} \cdot \mathrm{L}^{-1}(C), 75 \mathrm{mg} \cdot \mathrm{L}^{-1}(D)$, and $100 \mathrm{mg} \cdot \mathrm{L}^{-1}(E)$. Parameters observed in this research were the survival rate, osmotic work level, oxygen consumption level, calcium levels of postlarvae's body and chemical-physical of media. The result showed that the best calcium addition was $50 \mathrm{mg} \cdot \mathrm{L}^{-1}$ (C), because it could reduce the osmotic work level until $192.90 \mathrm{mOsm} . \mathrm{l}^{-1} \mathrm{H}_{2} \mathrm{O}$, and oxygen consumption rate $2.678 \mathrm{mgO}_{2} . \mathrm{g}^{-1}$. hour ${ }^{l}$. It also could increase the body's calcium levels up to $8,029 \mathrm{mg} / \mathrm{L}$ and obtain survival rate until $94 \%$. Physical and chemical value of media during the adaptation period (temperature, $\mathrm{pH}$, dissolved oxygen, ammonia, and alkalinity) were still in appropriate range for the survival rate of giant fresh water prawn postlarvae.
\end{abstract}

KEYWORDS: calcium, swamp, salinity, adaptation, giant prawn, postlarvae

\section{PENDAHULUAN}

Udang galah merupakan salah satu komoditas perikanan yang banyak dibudidayakan karena mempunyai beberapa kelebihan antara lain memiliki prospek pasar yang cerah, bernilai ekonomis tinggi, mudah dibudidayakan, serta memberikan keuntungan usaha yang cukup tinggi. Penyebaran udang galah juga cukup luas, di mana dalam daur hidupnya udang galah memiliki dua habitat perairan berbeda, air tawar dan payau (Kordi, 2009). Udang galah dewasa hidup pada perairan tawar, namun ketika akan memijah udang galah akan bermigrasi ke perairan yang bersalinitas sehingga larva yang dihasilkan akan hidup di perairan payau. Dalam perpindahan media hidup bersalinitas ini diperlukan suatu upaya untuk mempertahankan tekanan osmotik cairan tubuh supaya tidak berbeda jauh dengan tekanan osmotik medianya, sehingga dalam kondisi demikian udang tidak melakukan proses osmoregulasi dengan menggunakan energi yang cukup besar (Abidin, 2011).

Masalah yang sering dijumpai pada unit pembenihan khususnya pada tahap peme- liharaan larva udang galah di sentra pembenihan air tawar adalah tingkat mortalitas larva udang galah yang terjadi masih sangat tinggi terutama pada fase kritis saat pergantian media hidup ke perairan tawar, terlebih pada perairan yang berbatasan dengan daerah rawa (Taqwa et al., 2012 dan 2013). Hamzah (2004) menyatakan bahwa masalah yang dihadapi sehubungan perubahan salinitas tersebut sangat berkaitan dengan tekanan osmotik dan ionik air, baik air sebagai media internal maupun eksternal. Senyawa kimia perairan, penyakit mikrobial, dan rendahnya kemampuan regulasi ionik terhadap perubahan salinitas media dapat menyebabkan mortalitas yang tinggi pada pembenihan udang galah (Syafei, 2006).

Penelitian lain yang dilakukan oleh Charryani (2007), menyatakan bahwa penurunan salinitas yang dilakukan pada saat larva udang galah berumur 49 hari, dari salinitas 12 ppt menjadi 0 ppt, sintasan udang galah yang didapatkan masih sangat rendah yaitu $20,67 \%$. Salah satu langkah strategis yang dapat dilakukan untuk mengatasi kondisi lingkungan perairan terutama rawa yang kurang maksimal 
sebagai media hidup untuk budidaya udang galah ialah melalui optimasi media aklimatisasi hingga benih yang dihasilkan mampu beradaptasi dan mempunyai kondisi yang prima untuk dibudidayakan di perairan rawa yang mempunyai $\mathrm{pH}$ air cenderung asam.

Teknik adaptasi diperlukan untuk menekan mortalitas dengan perbaikan karakteristik lingkungan media adaptasi, salah satunya melalui penambahan mineral kalsium. Mineral kalsium digunakan karena kalsium berperan dalam pembentukan eksoskeleton pada udang dan mempercepat proses pergantian kulit udang. Pada masa pemeliharaan larva udang galah, kalsium juga berperan dalam proses osmoregulasi (Abidin, 201 1). Tseng (1987) menyatakan jika kandungan kalsium di perairan tidak mencukupi maka mekanisme osmoregulasi udang akan terganggu. Penelitian ini ditujukan untuk menentukan penambahan kadar kalsium terbaik yang dapat meningkatkan sintasan, mengefisienkan tingkat kerja osmotik, dan tingkat konsumsi oksigen pascalarva udang galah selama masa adaptasi pergantian media hidup dari media bersalinitas 12 ppt ke-0 ppt mulai dari stadia $\mathrm{PL}_{1}$ hingga $\mathrm{PL}_{11}$ yang menggunakan air rawa pengencer.

\section{BAHAN DAN METODE}

Penelitian dilaksanakan di hatcheri rawa Laboratorium Budidaya Perairan, Program Studi Akuakultur, Fakultas Pertanian Universitas Sriwijaya. Rancangan yang digunakan adalah Rancangan Acak Lengkap (RAL) dengan lima perlakuan dan tiga kali ulangan. Perlakuan yang diterapkan ialah penambahan $\mathrm{CaCO} 3$ dengan dosis berbeda pada media air rawa $(0$ mg. $\mathrm{L}^{-1}, 25 \mathrm{mg} \cdot \mathrm{L}^{-1}, 50 \mathrm{mg} \cdot \mathrm{L}^{-1}, 75 \mathrm{mg} \cdot \mathrm{L}^{-1}$, dan 100 $\left.\mathrm{mg} \cdot \mathrm{L}^{-1}\right)$, yang digunakan dalam proses penurunan nilai salinitas media. Penelitian dilakukan selama sepuluh hari sampai salinitas media menurun dari 12 ppt hingga mencapai 0 ppt. Larva yang digunakan berasal dari hatcheri udang galah di Sukabumi, Jawa Barat. Penurunan salinitas dilakukan secara gradual dengan tingkat penurunan sebesar 2 ppt setiap 24 jam dengan air rawa yang telah ditambahkan kalsium sesuai perlakuan hingga mencapai salinitas 4 ppt, dan selanjutnya diturunkan lagi setiap kurun waktu 24 jam hingga tercapai salinitas 3 ppt; 2 ppt; 1,5 ppt; dan 1 ppt. Tahap berikutnya untuk mencapai $0 \mathrm{ppt}$, metode pengenceran yang digunakan yaitu pergantian volume air. Pada hari ke- 8 , volume air dikurangi $25 \%$ dan selanjutnya di- tambahkan air rawa pengencer sesuai perlakuan sebanyak air yang dikurangi tersebut selama 24 jam secara gradual dan kontinu. Pada hari ke-9 dilakukan dengan cara yang sama namun dengan pengurangan volume air dan pergantian masing-masing sebanyak $50 \%$ dari volume total.

Padat tebar larva yang digunakan sebanyak 150 ekor dalam empat liter air bersalinitas 12 ppt (sebelum pengenceran) pada masing-masing akuarium $40 \mathrm{~cm} \times 40 \mathrm{~cm} \times 40 \mathrm{~cm}$. Pakan yang diberikan berupa pelet udang bentuk crumble kadar protein $40 \%$ secara ad satitation dengan frekuensi empat kali sehari. Parameter fisika kimia air yang diukur selama penelitian adalah suhu (termometer, $\pm 1^{\circ} \mathrm{C}$ ), salinitas (refraktometer, $\pm 1 \mathrm{ppt}$ ), oksigen terlarut (DO-meter, $\left.\pm 0,01 \mathrm{mg} \cdot \mathrm{L}^{-1}\right)$ dan $\mathrm{pH}(\mathrm{pH}$ meter, $\pm 0,01$ unit $\mathrm{pH}$ ) dilakukan setiap hari dengan frekuensi dua kali yaitu pada pukul 08.00 WIB dan pukul 16.00 WIB. Kadar kalsium media diukur dengan menggunakan metode AAS (Atomic Absorbtion Spectrophotometer) (Davis et al., 2002 dalam Taqwa et al., 2008), amonia dan alkalinitas media (spektrofo-

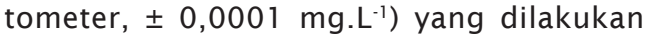
pengukuran pada awal dan akhir adaptasi. Penghitungan nilai sintasan dan tingkat kerja osmotik udang galah dilakukan pada hari ke10 (stadia $\mathrm{PL}_{11}$ ). Pengukuran tingkat konsumsi oksigen pada kondisi basal dilakukan pada hari ke-11 karena sebelumnya dipuasakan selama 24 jam. Pengukuran parameter fisika kimia berdasarkan metode APHA (1976), sintasan, tingkat kerja osmotik, dan konsumsi oksigen masing-masing berdasarkan acuan Effendie (2002), Anggoro (1992), dan Liao \& Huang (1975), serta kadar kalsium tubuh PL udang galah berdasar Davis et al. (2002) dalam Taqwa et al. (2008). Data sintasan dan tingkat kerja osmotik pascalarva udang galah diuji statistik dengan analisis ragam pada taraf $95 \%$, dan apabila terdapat perbedaan yang nyata antar nilai tengah maka diuji lanjut BNJ sedangkan untuk data lainnya dianalisis secara deskriptif.

\section{HASIL DAN BAHASAN}

Sintasan dan tingkat kerja osmotik pascalarva udang galah pada setiap perlakuan dengan penambahan kalsium disajikan pada Gambar 1. Perlakuan C dengan penambahan $50 \mathrm{mg}^{\mathrm{L}^{-1}} \mathrm{kalsium}$ pada air rawa pengencer salinitas dari 12 ppt sampai 0 ppt merupakan perlakuan terbaik karena memperoleh sintasan tertinggi di antara perlakuan lainnya yaitu rata- 


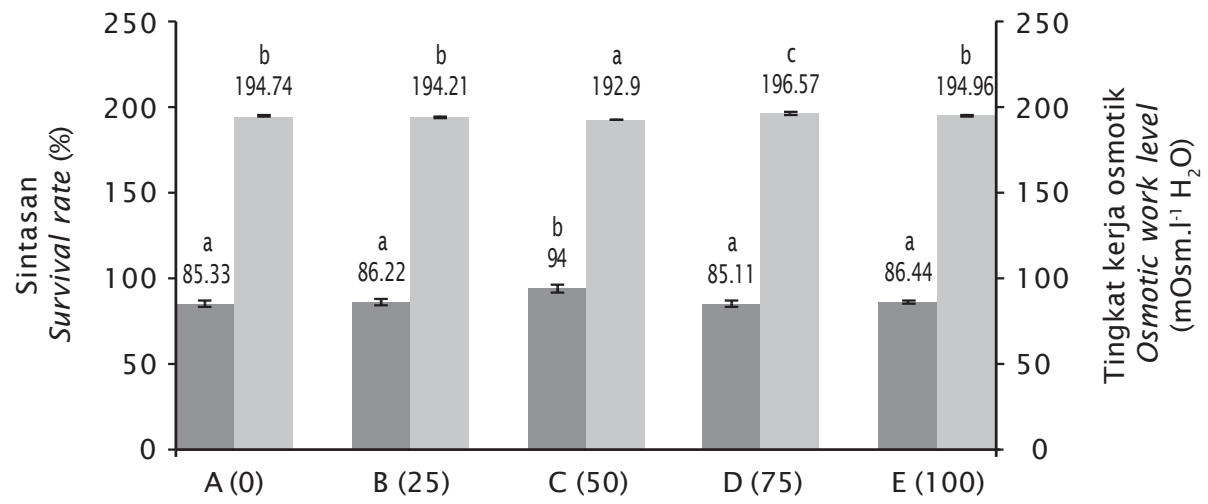

Perlakuan (Penambahan kalsium)

Treatments (Addition of calcium) (mg. $\left.\mathrm{L}^{-1}\right)$

Rata-rata sintasan (Average of survival rate)

Rata-rata tingkat kerja osmotik (Average of osmotic work level)

Keterangan (Note):

Huruf superscript yang berbeda di belakang nilai hasil pengamatan parameter pada diagram dengan arsiran yang sama menunjukan perbedaan yang nyata antar perlakuan ( $\mathrm{Val}$ ues with the different letter behind bar chart on the same shading are significantly different between treatment)

Gambar 1. Rata-rata sintasan dan tingkat kerja osmotik pascalarva udang galah pada setiap perlakuan dengan penambahan kalsium

Figure 1. Average survival rate and osmotic work level of giant freshwater prawns postlarvae on each treatment with the addition of calcium

rata sebesar $94 \%$. Hasil analisis ragam dan uji lanjut data sintasan dengan metode BNJ, perlakuan A, B, D, dan E tidak menunjukkan perbedaan yang nyata antar perlakuan, tetapi pada perlakuan $\mathrm{C}$ terdapat perbedaan yang nyata dari perlakuan lainnya. Hal ini menunjukkan bahwa titik optimum penambahan kalsium yaitu $50 \mathrm{mg} \cdot \mathrm{L}^{-1}$, jika penambahan kalsium lebih dari 50 mg. $\mathrm{L}^{-1}$, maka sintasan pascalarva udang galah akan menurun. Pada perlakuan $\mathrm{D}$ dan $\mathrm{E}$, sintasan mulai menurun, hal ini diduga terdapat keterkaitan antara semakin tingginya penambahan kalsium dengan pembelanjaan energi yang dibutuhkan pascalarva udang galah untuk proses osmoregulasi dan penyerapan kalsium dari media ke tubuh, serta tingkat stres yang tinggi sehingga memengaruhi sintasan. Penelitian Cameron (1985) menunjukkan bahwa kadar kalsium yang terlalu tinggi dapat menghambat transfer kalsium dari media ke dalam tubuh udang. Menurut Kaligis (2005), bahwa semakin tinggi tingkat kerja osmotik maka semakin tinggi tingkat stres dari udang tersebut sehingga memengaruhi pertumbuhan dan sintasan udang.
Penambahan kalsium terbukti memberikan pengaruh signifikan terhadap tingkat kerja osmotik, di mana ketika terjadi penambahan kalsium hingga $50 \mathrm{mg}^{\mathrm{L}} \mathrm{L}^{-1}$ maka tingkat kerja osmotik akan menurun, namun ketika lebih dari dosis tersebut tingkat kerja osmotik pascalarva udang galah akan meningkat kembali. Tingkat kerja osmotik terendah diperoleh pada perlakuan $C$ yaitu sebesar 192,90 mOsm.l ${ }^{-1}$ $\mathrm{H}_{2} \mathrm{O}$, dan terdapat perbedaan yang nyata dengan perlakuan lainnya. Kaligis et al. (2009) menyatakan jika penambahan kalsium melebihi batas optimum, nilai osmolaritas media akan naik sesuai dengan kelarutan kalsium yang tinggi di media sehingga terjadi selisih yang besar antara osmolaritas tubuh dan osmolaritas media. Pada perlakuan D, terjadi peningkatan tingkat kerja osmotik tertinggi bahkan melebihi perlakuan A dan E. Dalam hal ini tingkat kerja osmotik diduga dipengaruhi oleh perbedaan siklus moulting pada pascalarva udang galah, yang berkaitan dengan dosis kalsium yang diterapkan. Ketika terjadi pergantian kulit, daya osmolaritas udang akan semakin kecil. Berdasarkan penelitian Wilder et al. (2009) bahwa osmolaritas hemolim berkaitan erat dengan 
proses dan siklus moulting pada udang, di mana pada saat fase post-moult nilai osmolaritas hemolim udang sangat rendah.

Pengaruh penambahan kalsium ke media adaptasi menyebabkan variasi nilai tingkat konsumsi oksigen dan kadar kalsium tubuh pascalarva udang galah di akhir masa adaptasi (Tabel 1). Tingkat konsumsi oksigen tertinggi terdapat pada perlakuan penambahan kalsium $25 \mathrm{mg} \cdot \mathrm{L}^{-1}$ yaitu $3,240 \mathrm{mgO}_{2} \cdot \mathrm{g}^{-1} \cdot \mathrm{h}^{-1}$, sedangkan tingkat konsumsi oksigen terendah terdapat pada perlakuan dengan penambahan $50 \mathrm{mg} \cdot \mathrm{L}^{-1}$ kalsium yaitu $2,678 \mathrm{mgO}_{2} \cdot \mathrm{g}^{-1} \cdot \mathrm{h}^{-1}$, semakin rendah nilai tingkat konsumsi oksigen pada metode pengukuran metabolisme basal maka akan semakin rendah tingkat stres pascalarva udang galah tersebut. Jika konsumsi oksigen semakin tinggi, maka energi yang digunakan akan semakin besar sehingga menyebabkan pertumbuhan akan semakin lambat. Tingkat konsumsi oksigen adalah jumlah oksigen dalam proses oksidasi untuk memperoleh energi (Syafei, 2006). Faktor lingkungan yang memengaruhi tingkat konsumsi oksigen di antaranya adalah salinitas, suhu, dan tingkatan aktivitas (Brett, 1987). Tingkat konsumsi oksigen makin rendah maka semakin sedikit energi yang digunakan untuk metabolisme dan diharapkan makin banyak energi yang tersedia untuk pertumbuhan.

Kadar kalsium tubuh tertinggi yaitu pada perlakuan $C$ dengan penambahan $50 \mathrm{mg}^{-\mathrm{L}^{-1}}$ $\mathrm{CaCO}_{3}$ sebesar $8.029 \mathrm{mg} / \mathrm{L}$ dan terendah pada perlakuan B yaitu $5.598 \mathrm{mg} / \mathrm{L}$. Semakin banyak kalsium yang ditambahkan di media adaptasi, tidak membuktikan semakin tinggi kadar kalsium tubuh karena terdapat titik optimum penambahan kalsium di media yang bisa terserap ke dalam tubuh udang sebagaimana pernyataan Adegboye (1981), bahwa kadar kalsium media yang rendah akan menyulitkan udang untuk pembentukan cangkang, akan tetapi kadar kalsium yang terlalu tinggi juga menyulitkan proses homeostatis ion kalsium. Di sisi lain, bila kadar kalsium terlalu tinggi maka dapat menghambat transfer kalsium dari lingkungan ke dalam tubuh udang (Cameron, 1985). Kalsium dalam tubuh udang merupakan indikator yang baik bagi kemajuan mineralisasi (Zaidy, 2007). Kalsium merupakan kation terpenting di antara seluruh ion anorganik yang berperan dalam proses fisiologis krustasea (Robertson, 1941 dalam France, 1981). Kalsium juga dapat menaikkan $\mathrm{pH}$ terutama kalsium karbonat dan kalsium oksida yang disebabkan terhidrolisisnya karbonat menjadi ion hidroksil sehingga meskipun media adaptasi menggunakan air rawa namun tetap meminimalisir tingkat keasaman tersebut (Zaidy, 2007).

Hasil pengukuran fisika kimia media meliputi: suhu, oksigen terlarut, $\mathrm{pH}$, amonia, dan alkalinitas disajikan pada Tabel 2. Rata-rata suhu pada media adaptasi berkisar antara $28,85^{\circ} \mathrm{C}-29,05^{\circ} \mathrm{C}$. Suhu tersebut masih dalam kondisi optimal untuk mendukung sintasan udang galah. Seperti dinyatakan oleh Abidin (2011) bahwa kisaran suhu optimum pemeliharaan larva udang galah adalah $24^{\circ} \mathrm{C}-31^{\circ} \mathrm{C}$. Pada suhu di bawah $24^{\circ} \mathrm{C}$ larva udang tidak dapat tumbuh dengan baik dan waktu metamorfosis lebih panjang. Perubahan suhu secara drastis akan menyebabkan kematian pada larva udang, akan tetapi perubahan secara bertahap tidak banyak berpengaruh terhadap

Tabel 1. Tingkat konsumsi oksigen dan kadar kalsium tubuh pascalarva udang galah pada akhir adaptasi

Table 1. Oxygen consumption and calcium levels of postlarvae's body on the end of adaptation

\begin{tabular}{|c|c|c|}
\hline $\begin{array}{l}\text { Perlakuan (Penambahan } \\
\text { kalsium) } \\
\text { Treatments (Addition of } \\
\text { calcium) }\left(\mathrm{mg}^{\left.-\mathrm{L}^{-1}\right)}\right.\end{array}$ & $\begin{array}{l}\text { Tingkat konsumsi oksigen } \\
\text { Oxygen consumption rate } \\
\qquad\left(\mathrm{mgO}_{2} \cdot \mathrm{g}^{-1} \cdot \mathrm{h}^{-1}\right)\end{array}$ & $\begin{array}{c}\text { Kadar kalsium tubuh } \\
\text { Body calcium content } \\
\left(\mathrm{mg} \cdot \mathrm{L}^{-1}\right)\end{array}$ \\
\hline$A(0)$ & 3,216 & 5.832 \\
\hline B (25) & 3,240 & 5.598 \\
\hline$C(50)$ & 2,678 & 8.029 \\
\hline $\mathrm{D}(75)$ & 2,775 & 6.948 \\
\hline$E(100)$ & 2,736 & 6.052 \\
\hline
\end{tabular}


Tabel 2. Rata-rata nilai fisika kimia media adaptasi selama penelitian

Table 2. Average of chemical physical value on adaptation media during research

\begin{tabular}{|c|c|c|c|c|c|}
\hline $\begin{array}{l}\text { Perlakuan } \\
\text { Treatments } \\
\quad\left(\mathrm{mg} \cdot \mathrm{L}^{-1}\right)\end{array}$ & $\begin{array}{c}\text { Suhu } \\
\text { Temperat ure } \\
\left({ }^{\circ} \mathrm{C}\right)\end{array}$ & $\begin{array}{c}\text { Oksigen terlarut } \\
\text { Dissolved oxygen } \\
\quad\left(\mathrm{mg} \cdot \mathrm{L}^{-1}\right)\end{array}$ & $\underset{\text { (unit) }}{\mathbf{p H}}$ & $\begin{array}{l}\text { Amonia } \\
\text { Ammonia } \\
\left(\mathrm{mg} \cdot \mathrm{L}^{-1}\right)\end{array}$ & $\begin{array}{c}\text { Alkalinitas } \\
\text { Alkalinity } \\
\left(\mathrm{mg}^{-\mathrm{L}^{-1}}\right)\end{array}$ \\
\hline$A(0)$ & $29.05 \pm 1.32$ & $6.97 \pm 0.52$ & $6.97 \pm 0,19$ & $0.065 \pm 0.08$ & $14 \pm 8.49$ \\
\hline B (25) & $28.85 \pm 1.46$ & $6.98 \pm 0.50$ & $7.10 \pm 0.20$ & $0.066 \pm 0.08$ & $17 \pm 4.24$ \\
\hline$C(50)$ & $28.75 \pm 1.55$ & $6.96 \pm 0.52$ & $7.14 \pm 0.18$ & $0.079 \pm 0.06$ & $18 \pm 2.83$ \\
\hline $\mathrm{D}(75)$ & $28.95 \pm 1.50$ & $6.72 \pm 0.72$ & $7.16 \pm 0.18$ & $0.067 \pm 0.08$ & $20 \pm 0.00$ \\
\hline$E(100)$ & $28.85 \pm 1.53$ & $6.98 \pm 0.69$ & $7.21 \pm 0.20$ & $0.071 \pm 0.07$ & $26 \pm 8.48$ \\
\hline
\end{tabular}

kehidupan larva udang. Suhu tinggi cenderung menyebabkan kadar oksigen terlarut menurun. Suhu dan kalsium merupakan variabel untuk mengontrol pertumbuhan dan sintasan udang (Holdich, 2002). Rata-rata nilai $\mathrm{pH}$ pada penelitian ini berkisar antara 6,97-7,21 (Tabel 2). Pada awal penelitian, $\mathrm{pH}$ cenderung asam yaitu 6,7 karena dalam penelitian ini menggunakan air rawa yang telah diendapkan. Namun setelah ditambahkan kalsium, pH media meningkat hingga lebih dari 7,0 di akhir masa adaptasi. Law et al. (2002) dan Boyd (1998) menyatakan bahwa pH air pada kisaran netral merupakan nilai keasaman yang mendukung kehidupan larva udang galah. Hasil kajian Cheng et al. (2003) menunjukkan bahwa terjadi penurunan $\mathrm{pH}$ media dari 7,4 menjadi 7,34; jika kandungan oksigen terlarut pada media menurun dari $4,30 \mathrm{mg} \cdot \mathrm{L}^{-1}$ menjadi 2,14 mg.L-1.

Rata-rata kadar oksigen terlarut terendah yaitu $6,72 \mathrm{mg} \cdot \mathrm{L}^{-1}$ terdapat pada perlakuan $D$ (75 mg. $\mathrm{L}^{-1} \mathrm{CaCO}_{3}$ ) dan oksigen terlarut tertinggi pada perlakuan B dan E (25 dan 100 mg. $\mathrm{L}^{-1} \mathrm{CaCO}_{3}$ ) yaitu $6,98 \mathrm{mg} \cdot \mathrm{L}^{-1}$. Menurut Zaidy (2007), kandungan oksigen terlarut dalam penelitian ini masih dalam kondisi optimal karena lebih dari $5 \mathrm{mg} . \mathrm{L}^{-1}$, sehingga masih mendukung sintasan pascalarva udang galah selama masa adaptasi penurunan salinitas. Rata-rata nilai amonia selama penelitian ini berkisar antara 0,065 mg. $\mathrm{L}^{-1}$ hingga $0,079 \mathrm{mg} \cdot \mathrm{L}^{-1}$. Berdasarkan Boyd \& Zimmermann (2000) sebaiknya amonia diusahakan lebih kecil dari $0,1 \mathrm{mg} \cdot \mathrm{L}^{-1}$. Rata-rata amonia yang dihasilkan pada pengukuran akhir lebih kecil dari 0,1 mg. $\mathrm{L}^{-1}$; hal ini dikarenakan pada masa adaptasi dilakukan penyiponan secara rutin sehingga dapat meminimalisir stres dan meningkatkan sintasan. Senyawa amonia yang beracun be- rada dalam bentuk amonia bukan ion. Oleh karena itu, jika kadar amonia dalam air meningkat, maka ekskresi amonia menurun dan kadar amonia dalam darah, serta jaringan lain meningkat. Kondisi ini mengakibatkan suatu elevasi $\mathrm{pH}$ darah dan menimbulkan efek merugikan pada stabilitas membran dan reaksi katalisasi enzim yang menyebabkan kematian (Tomasso, 1994). Rata-rata nilai alkalinitas selama penelitian untuk semua perlakuan meningkat seiring tingkat penambahan kalsium ke media air rawa pengencer salinitas, yaitu berkisar antara 14-26 mg. L-1. Penelitian Adhikari et al. (2007) menyatakan bahwa kalsium dan karbonat memengaruhi kandungan alkalinitas pada perairan. Alkalinitas yang terlalu tinggi dapat menyebabkan rendahnya sintasan bagi pascalarva udang galah karena dapat mengganggu proses kalsifikasi udang secara normal.

\section{KESIMPULAN DAN SARAN}

Penambahan kalsium terbaik pada media air rawa pengencer selama masa penurunan salinitas dari 12 ppt hingga 0 ppt terhadap sintasan, tingkat kerja osmotik, dan tingkat konsumsi oksigen bagi pascalarva udang galah adalah sebanyak $50 \mathrm{mg} \cdot \mathrm{L}^{-1} \mathrm{CaCO}_{3}$. Masih perlu kajian mengenai peranan kalsium terhadap frekuensi, periode moulting dan laju pertumbuhan pascalarva udang galah selama sepuluh hari dari $\mathrm{PL}_{1}$ sampai $\mathrm{PL}_{11}$ selama masa penurunan salinitas dari $12 \mathrm{ppt}$ hingga 0 ppt.

\section{UCAPAN TERIMA KASIH}

Ucapan terimakasih disampaikan kepada Program Studi Akuakultur, Fakultas Pertanian Universitas Sriwijaya, Pusat Unggulan Riset Pengembangan Lahan Suboptimal (PUR-PLSO) 
Unsri, Balai Penelitian Perikanan Perairan Umum (BP3U) Palembang, serta Balai Penelitian dan Pengembangan Budidaya Ikan Hias, Depok, Jawa Barat atas bantuan, kerja sama dan dukungannya. Penelitian ini terlaksana atas dana Insentif Riset Sistem Inovasi Nasional, Kementerian Riset dan Teknologi Republik Indonesia Tahun Anggaran 2012.

\section{DAFTAR ACUAN}

Abidin, J. 2011 . Penambahan kalsium untuk meningkatkan kelangsungan hidup dan pertumbuhan juvenile udang galah (Macrobrachium rosenbergii de Man) pada media bersalinitas. Tesis. Institut Pertanian Bogor. Bogor, $57 \mathrm{hlm}$.

Adegboye, J.O.D. 1981. Table size and physiological condition of the crayfish in relation to calcium ion acumulation. In Goldman, R.C. (Ed.), Paper from the $5^{\text {th }}$ International Symposium on Freshwater Crayfish. Davis. California. USA, p. 115-125.

Adhikari, S., Chaurasia, V.S., Naqvi, A.A., \& Pillai, B.R. 2006. Survival and growth of Macrobrachium rosenbergii (de Man) juvenile in relation to calcium hardness and bicarbonate alkalinity. Turkish Journal of Fisheries and Aquatic Sciences, 7: 23-26.

Anggoro, S. 1992. Efek osmotik berbagai tingkat salinitas media terhadap daya tetas telur dan vitalitas larva udang windu (Penaeus monodon Fabricius). Disertasi. Institut Pertanian Bogor. Bogor, 230 pp.

American Public Health Association (APHA). 1976. Standard methods for the examination of water and wastewater. $4^{\text {th }}$ edition. American Public Health Association, Washington D.C., 1,193 pp.

Boyd, C.E. 1998. Water quality in ponds for aquaculture. Auburn University, Alabama. Birmingham Publishing Co. 482 pp.

Boyd, C.E. \& Zimmerman, S. 2000. Grow-out systems-water quality and soil management. In New, M.B. \& Valenti, W.C. (Eds.), Freshwater prawn culture: the farming of Macrobrachium rosenbergii. Oxford, England, Blackwell Science. 221-238 pp.

Brett, J. 1987. Environmental factors affecting growth. In Hoare, D.J., Randal, S.R., \& Brett, S. (Eds.). Academic Press. Fish Physiologi, 8: 252-259.

Cameron, J.N. 1985. Post-moult calcification in the blue crab (Callinectus sapidus): Relationships between apparent net $\mathrm{H}^{+}$excretion, calcium, and bicarbonate. J. Exp. Biol.,

\section{9: 275-285.}

Charryani, E. 2007. Kelangsungan hidup dan pertumbuhan udang galah (Macrobrachium rosenbergii de Man) $\left(D_{21}-D_{49}\right)$ pada berbagai tingkat penurunan salinitas. Skripsi. Fakultas Pertanian. Universitas Sriwijaya. Palembang, $57 \mathrm{hlm}$.

Cheng, W., Liu, C.H., Cheng, C.H., \& Chen, J.C. 2003. Osmolality and ion balance in giant river prawn Macrobrachium rosenbergii subjected to changes in salinity: role of sex. J. Aquaculture Research, 34: 555-560.

Effendie, M.I. 2002. Biologi perikanan. Yayasan Pustaka Nusatama. Yogyakarta, $163 \mathrm{hlm}$.

France, R.L. 1981. Response of crayfish Orconectes virillis to experimental acidification of the lake with special reference to the importance calcium. In Goldman, R.C (Ed.), Paper from the $5^{\text {th }}$ International Symposium on Freshwater Crayfish. Davis. California. USA, p. 98-111.

Hamzah, M. 2004. Kelangsungan hidup dan pertumbuhan juvenil udang galah (Macrobrachium rosenbergii de Man) pada berbagai tingkat salinitas media. Tesis S2. Institut Pertanian Bogor. Bogor, $70 \mathrm{hlm}$.

Holdich, D.M. 2002. Background and functional morphology. In Holdich, D.M. (Ed.), Biology of Freshwater Crayfish. Blackwell Science. United Kingdom, p. 3-26.

Kaligis, E.Y. 2005. Pertumbuhan dan sintasan postlarva lobster air tawar (Cherax quadricarinatus, von Martens) pada media alkalinitas rendah. Tesis. Program Pascasarjana. Institut Pertanian Bogor. Bogor, 61 hlm.

Kaligis, E.Y., Djokosetiyanto, D., \& Affandi, R. 2009. Pengaruh penambahan kalsium dan salinitas aklimasi terhadap peningkatan sintasan post larva udang vaname (Litopenaeus vannamei, Boone). J. Kelautan Nasional, 2: 101-108.

Kordi, M.G.H. 2009. Budidaya perairan. Buku kedua. Citra Aditya Bakti. Bandung, $964 \mathrm{hlm}$.

Law, A.T., Wong, Y.H., \& Munafi, A.B. 2002. Effect of hydrogen ion on Macrobrachium rosenbergii (de Man) egg hatchability in brackishwater. Aquaculture, 214:247-251.

Liao, I.C. \& Huang, H.J. 1975. Studies on the respiration of economic prawns in Taiwan. I. Oxygen comsumption and lethal dissolved oxygen of egg up to young prawns of Penaeus monodon Fab. J. Fish. Soc. Taiwan, 4(1): 33-50.

Syafei, L.S. 2006. Pengaruh beban kerja osmo- 
tik terhadap kelangsungan hidup, lama waktu perkembangan larva udang galah dan potensi tumbuh pascalarva udang galah. Disertasi. Institut Pertanian Bogor. Bogor, $193 \mathrm{hlm}$.

Taqwa, F.H., Sasanti, A.D., \& Gaffar, A.K. 2012. Kelangsungan hidup, kerja osmotik dan konsumsi oksigen pascalarva udang galah selama penurunan salinitas dengan air rawa pengencer yang ditambahkan kalium. Prosiding Seminar Insentif Riset Sinas "Membangun Sinergi Riset Nasional untuk Kemandirian Teknologi". Bandung. Kemenristek RI. ISBN 978-602-18926-2-6. hlm. 98102.

Taqwa, F.H., Sasanti, A.D., Gaffar, A.K., \& Hitosi, Y.A. 2013. Vulnerability the quality improvement of giant freshwater prawns postlarvae (Macrobrachium rosenbergii) in swamp media with addition sodium during the acclimatization. Proceeding International Workshop on Sustainable Management of Lowland for Rice Production. Banjarmasin. Indonesian Agency For Agricultural Research And Development. Ministry of Agriculture. ISBN 978-602-8977-65-4. P. 389-394.
Taqwa, F.H., Djokosetiyanto, D., \& Affandi, R. 2008. Pengaruh penambahan kalium pada masa adaptasi penurunan salinitas terhadap performa pascalarva udang vaname (Litopenaeus vannamei). J. Ris. Akuakultur, 3(3): 431-436.

Tomasso, J.R. 1994. Toxicity of nitrogenous wastes to aquaculture animals. Rev. Fish. Sci., 2: 291-314.

Tseng, W.Y. 1987. Shrimp marine culture. Port Moresby. Department of Fisheries. Papua New Guinea University, 305 pp.

Wilder, M.C., Huong, D.T.T., Jasmani, S., Jayasankar, V., Kaneko, T., Aida, K., Hatta, T., Nemoto, S., \& Wiginton, A. 2009 Hemolymph osmolality, ion concentration and calcium in structural organization in cuticle of the giant fresh water prawn Macrobrachium rosenbergii: Changes with the molt cycle. J. Aquaculture, 292: 104-110.

Zaidy, A.B. 2007. Pendayagunaan kalsium media perairan dalam proses ganti kulit dan konsekuensinya bagi pertumbuhan udang galah (Macrobrachium rosenbergii de Man). Disertasi. Institut Pertanian Bogor. Bogor, $107 \mathrm{hlm}$. 